\title{
Strategy of Instagram Marketing and Implementation of Competitive Design Packaging at SMEs Guriyana Baker Through Business Coaching
}

\author{
Rakhmat Dicky Mohammad ${ }^{1}$ Sisdjiatmo Kusumosuwidho Widhaningrat ${ }^{1 *}$
}

\author{
${ }^{I}$ Master of Management, Faculty of Economics and Business University of Indonesia Jakarta, Indonesia \\ *Corresponding author. Email: sisdjiatmo@gmail.com
}

\begin{abstract}
Breads are one of the most delicious foods in Indonesia, especially in Jakarta. There are so many bread companies in Jakarta. To compete in this industry, SMEs should give much effort to survive. Guriyana Bakery is one of the SMEs that survive in this industry. They have a signature product, wide distribution network, and very good production system. One of the ways to develop these SMEs is by excellence promotion on the internet. The objectives of this research are to develop the digital market in order to maintain sales. This study is conducted using a qualitative method, and the data is obtained by observation, surveys, and in depth interviews. The writer utilized social media Instagram as a tool for promotion on the internet. The method writers use is based on instagram marketing strategies by combining several different outcomes. Starting from choosing the right profile photo, and creating visually compelling content. Also, based on evaluation from the questionnaire, writers conclude their packaging isn't competitive enough to evolve their leads. So basically, they have to redesign the packaging to be more competitive. The seven analytical tools to achieve the targeted results, namely Business Model Canvas (BMC), Porter's Five Forces, PESTEL Analysis, Service Marketing Mix, SWOT Analysis, TOWS Analysis, and GAP Analysis. These analyses are used as a base to generate the result of this study, as example applying website and social media sites for customers to order products.
\end{abstract}

Keywords: Small Micro Enterprise, Bakery Industry, Digital Marketing, Social Media, Instagram Marketing, Competitive Design Packaging

\section{INTRODUCTION}

\subsection{Background and Profile SMEs}

Since its founding in Jakarta in 1960, Guriyana Bakery has become one of the leading baking industries in Jakarta, with two factories in East Jakarta. The company has twenty employees and sixty selling partners with a business area spread around Jakarta. The company produces around five hundred to one thousand pieces of bread per day, depending on the customer demand.

This paper objective is to develop digital market in order to increasing sales Guriyana Bakery. The method used is content mapping, editorial plan and promote engagement. It will utilize seven analytical tools to achieve the targeted results, such as Business Model Canvas (BMC), Porter's Five Forces, PESTEL Analysis, Service Marketing Mix, SWOT Analysis, TOWS Analysis, and GAP analysis. The methodological approach will be through observation, surveys, and in depth interviews.
Here, we show that create instagram accounts which can improve the sales of Guriyana Bakery. The customer now can order Guriyana bakery via Instagram. Instagram will improve their sales area. To explore the improvement we use GAP analysis before and after use of the website. The customer feels the website is very helpful because they can order online and must not go find Guriyana Bakery carriage. These results establish Instagram as a good distribution channel for SMEs Guriyana Bakery.

\section{LITERATURE REVIEW}

\subsection{Social Media Marketing}

According to Nurgiyantoro (2014) that social media is when people want to share information and places to gather. It's supposed to find new friends and interact with other friends online. Another opinion was expressed by Obar \& Wildman (2015), social media is about interactive computermediated technologies that facilitate the creation or sharing of 
information, ideas, career interests and other forms of expression via virtual communities and networks.

\subsection{Instagram Marketing}

Instagram marketing is any form of marketing directly or indirectly used to build awareness, recognition, recollection, and action against a brand, business, product, person, or other thing packaged using Instagram platform (Gunelius, 2011). It is the way companies and organizations non-profit use Instagram effectively to build relationships through trust, useful content, help, and authority (Taprial \& Kanwar, 2012).

\section{RESULTS}

\subsection{Strategy of Instagram Marketing}

Instagram serves a global community of more than 1 billion people who are active every month (Hootsuite, 2019). People use Instagram to share moments, find passions, be inspired and take action. Instagram can help businesses of every size find customers and grow. With an Instagram business profile, businesses can promote their products and services to a global audience of people who are most interested in what they do.

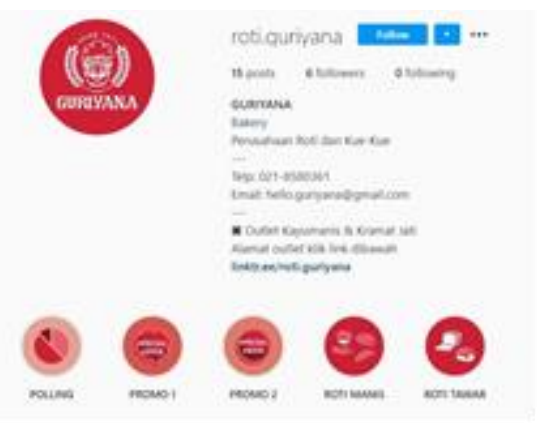

Fig 3.1 Ruti Guriyana's Instagram

Source: Proceeded by Author (2020)

Firstly, Roti Guriyana SMEs had to create an account on Instagram. Instagram can be played through an application on a smartphone, and is obtained through uploads on the app store on a smartphone (App Store and Google Play Store). Then, click the list with email or phone number. Enter email address, then verify. Create a username and password that will be used for an account. Creating an Instagram account is not used by personal purpose, then using the configuration of the name. So, Roti Guryana will make Instagram for business purposes, and include the name of the business being run.
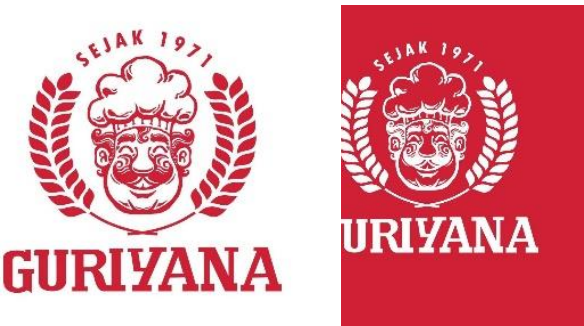

Fig 3.2 Roti Guriyana' Logo

Source: Proceeded by Author (2020)
According to the results of the coach's discussion with Dyah Sobari, owner of the SMEs, that profile photos should be included with the product name and year of establishment. While the overall design is submitted entirely by the coach. As listed in Figure 3.2 that, the head chef's logo symbolizes hope for success in the bakery industry, and the red and white colors symbolize encouragement of penetrating the market.

\subsection{Implementation of Competitive Design Roti Guriyana's Package}

According to Wijayanti (2014), a product packaging is an explicit information to give a message to consumers. Kotler and Armstrong (2012) argued, packaging is a form of activity that involves graphic design, so that the packaging is useful for consumers.

Product packaging that has been qualified, able to compete with the direct competitors of Roti Guriyana, because the products are oriented to be approved, bought, sold and used. There is packaging, can prevent or reduce damage, and protects the product inside
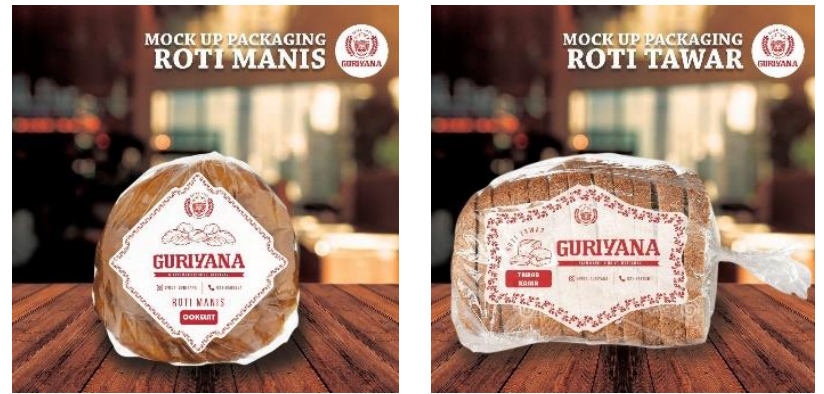

Fig 3.3 New Packaging of Roti Guriyana

Source: Proceeded by Author (2020)

Figure 3.3 shows that the packaging for Roti Guriyana has changed. That does not eliminate the brand image and association of Roti Guriyana, and also not changing the color of identity and some of the same ornaments.

\section{DISCUSSION}

Based on the analysis and observations on the conditions of the SMEs Roti Guriyana in business coaching activities, it can be concluded that the main problem that is a priority is the development of Roti Guriyana (Instagram) channel strategy. Meanwhile, they must consider the renewal of packaging, because of competitiveness issues. Based on a questionnaire that came up to the observations process, their consumers tend to predict the causality of packaging Roti Guriyana.

\subsection{Strategy of Instagram Marketing}

Before Roti Guriyana gets started with Instagram marketing, they need an Instagram for Business account or an Instagram Creator account. So, due to it's brand new here's what to do: Sign up with email or phone number; Create a username and password; Fill out profile info; Switch to a business account; Connect account to Facebook business page; Add your business details.

Roti Guriyana have to make their Instagram account a business account, because of instagram insight, ads, shopping, and contact information and call-to-action button on their profile.

Coach and Roti Guriyana's owner have to implement their Instagram marketing to define their goals clearly. It can mean 
looking to increase brand awareness, get new leads, establish brand as an industry leader, then make sales.

They also have to choose the right profile photo. For brand, Instagram profile photos should be their logo. This helps provide credibility and allows visitors to see at a glance who they are.

They also have to define their audience. This can be helped by a little preliminary research to figure out the best reach using Instagram. Create content that speaks directly to the audience.

\subsection{Implementation of Competitive Redesign Packaging}

Businesses everywhere are moving more quickly than ever before. This plan to redesign packaging of Roti Guriyana allows the brand to evolve fast and tap into new digital strategies. Coach and owner's tried-and-true creative process makes design look relevant. We plan to try creating eyecatching packaging designs that suit the product and stand out in the audience.

\section{CONCLUSION}

Roti Guriyana can be developed through several additional promotional methods such as through social media and websites. Marketing development through social media like Instagram encourage their marketing activities, as well as to increase sales.

Implementation of the redesign of the Roti Guriyana packaging aims to increase the level of competition with direct competitors of Roti Guriyana. Product packaging needs to be reviewed from packaging materials, packaging forms, and labels on packaging to influence consumer purchasing decisions.

It is hoped that by combining attractive packaging and social media such as Instagram, it will be able to change conventional businesses to become more modern so that they can attract new markets such as young people who use social media.

\section{REFERENCES}

[1] Amaly, L., \& Hudrasyah, H. "Measuring effectiveness of marketing communication using AISAS ARCAS model". Journal of Business and Management, 1(5), 352-364, 2012.

[2] Barry, T. E., \& Howard, D. J. "A review and critique of the hierarchy of effects in advertising". International Journal of Advertising, 9(2), 121-135, 1990.

[3] Brogan, C. "Social media 101: Tactics and tips to develop your business online". John Wiley \& Sons, 2010.

[4] Chaffey, D. and Smith, P.R.. eMarketing eXcellence: Planning and optimizing your digital marketing. Routledge, 2013.

[5] Chaffey, D. E-Business and E-Commerce Management, Strategy, Implementation \& Practice, Prentice Hall, 2009: E-Business and E-Commerce Management, Strategy, Implementation \& Practice (Vol. 1). Bukupedia, 2009

[6] Christopher. Lauren. Manajemen Pemasaran. Index. PT. Macanan Jaya Cemerlang. Jakarta, 2007

[7] De Veirman, M., Cauberghe, V. and Hudders, L. Marketing through Instagram influencers: the impact of number of followers and product divergence on brand attitude. International Journal of Advertising, 36(5), pp.798-828, 2017.
[8] Fred Hahn. Kenneth G Mangun. Do it Yourself Advertising dan Promotion. Beriklan dan Berpromosi Sendiri. Penerbit PT. Grasindo Jakarta, 2009.

[9] Fred Hahn. Kenneth G Mangun. Do it Yourself Advertising dan Promotion. Beriklan dan Berpromosi Sendiri. Penerbit PT. Grasindo Jakarta, 2009.

[13] UNEP. "Montreal Protocol On Substances That Deplete The Ozone Layer." 2016

[14] Ozone Depleting Substances. https://www.epa.gov/

[15] Honeywell Refrigerant. www.honeywell-refrigerants.com

[16] ANSI/ASHRAE Standard 34. "Designation and Safety Classification of Refrigerants." 